\title{
Growth of wheat as affected by fresh and composted poultry manure, urea and beneficial microbes
}

\author{
Adeel Liaqat ${ }^{1}$, Nangial Khan ${ }^{1,2^{*}}$, Farooq Nawaz ${ }^{1}$, Saif Ullah ${ }^{1}$, Zahir \\ Hussain $^{1}$ and Abdur Rauf Khan ${ }^{1}$ \\ 1. Department of Agronomy, The University of Agriculture, Peshawar-Pakistan \\ 2. State Key Laboratory of Cotton Biology, Institute of Cotton Research, Chinese Academy of Agricultural \\ Sciences, Anyang, Henan-China \\ *Corresponding author's email: nangialkhan@aup.edu.pk \\ Citation \\ Adeel Liaqat, Nangial Khan, Farooq Nawaz, Saif Ullah, Zahir Hussain and Abdur Rauf Khan. Growth of wheat \\ as affected by fresh and composted poultry manure, urea and beneficial microbes. Pure and Applied Biology. \\ Vol. 8, Issue 2, pp1408-1419. http://dx.doi.org/10.19045/bspab.2019.80081

\begin{tabular}{llll}
\hline \hline Received: 29/01/2019 & Revised: 24/04/2019 & Accepted: 30/04/2019 & Online First: 06/05/2019 \\
\hline
\end{tabular}

\section{Abstract}

Organic manures can be used to increase crop growth, productivity and sustainability. Organic manures applications without processing have low potential to supply nutrients in short time. In this experiment different treatments were applied as source of nitrogen and $120 \mathrm{~kg} \mathrm{~N} \mathrm{ha}^{-1}$ was desired from each single treatment or combination of treatments. The different treatments were comprised of poultry manure composted (PMC) for various durations i.e. 5, 10, 15 and 20 days. Two composting conditions were used i.e. one sole composted poultry manure and the other was integrated with half nitrogen from urea. Beneficial microbes (BM) were applied in two levels i.e. no BM and $50 \mathrm{~L} \mathrm{ha}^{-1}$. Sole treatment of poultry manure only, machine compost, urea only, a combination of urea and poultry manure in 50:50 ratio and a control treatment for mean comparisons were also used. The results of the experiment indicated that different composting duration significantly affected days to anthesis, leaf area $\operatorname{tiller}^{-1}$, leaf area index, days to maturity and plant height. Higher values were recorded with compost duration of 15 days except days to anthesis and plant height which were higher with compost duration of 20 days. Moreover addition of compost along with urea in 50:50 ratio increased days to anthesis, leaf area, leaf area index, days to maturity and plant height. Application of beneficial microorganisms at the rate of $50 \mathrm{~L} \mathrm{ha}^{-1}$ increased crop growth. The fertilized treatment in comparison with control treatment was found superior in terms of growth. The pit compost in comparison with machine compost performs better and increased growth and yield. It is concluded that compost duration of 15 days when applied in 50:50 ratio with urea increased crop growth and yield and thus recommended for general cultivation of wheat crop.

Keywords: Beneficial microbes; Composted poultry manure; Fresh poultry manure; Growth; Wheat and Urea

\section{Introduction}

Wheat (Triticum aestivum L.) is most important crop amongst the cereals in terms of production and consumption. Wheat was cultivated on about 9.25 million ha with total production of 25.5 million ton, having an average yield of $2873 \mathrm{~kg} \mathrm{ha}^{-1}$ while in Khyber Pakhtunkhwa province area under cultivation was 0.75 million ha having production of about 1.4 million ton with the average yield of $2359 \mathrm{~kg} \mathrm{ha}^{-1}[1]$. In Asia Pakistan is the third-largest producer of wheat where annual consumption of wheat is around 23 million ton that will leave the country with a surplus of a few ton that can be exported [2].With rapidly increasing population rate generally in world and specifically in Pakistan food and feed shortages are being faced. But the resources 
available for wheat production are likely to be significantly lower [3].

The use of chemical fertilizer was at its top after that period which resulted in soil depletion and contamination of environment and increasing production cost [4]. Soil depletion is a major factor in low crop productivity and continuous use of chemical fertilizer is not only hazardous for health but also cause nutrient depletion in soil. The applied chemical fertilizer mostly leach down and contaminate the ground water which is the main source of drinking water and lead to cause certain disorders in human[5].

Different waste materials generated on different types of farms including farmyard manure, poultry manure, animal excreta, green manure and crop residues which are best option to substitute chemical fertilizer when utilize in an efficient way [6]. Several researchers had reported the beneficial effects of these organic materials when used as fertilizer. It not only improves crop productivity but also improves soil health and properties [7].

Since soil fertility is the main factor in boosting crop production, therefore it is a prerequisite to improve soil health and fertility in order to achieve sustainability in crop production on long term basis. This is neither possible with applying chemical fertilizer only nor with application of organic manures only [8]. Therefore integrated approaches should be practiced by combine use of organic and inorganic fertilizers which not only increase crop yield on sustainable basis but also will improve soil properties and nutrient status [9]. Application of synthetic fertilizer along with composted organic material increased yield as well as nutrient uptake by wheat as compared to inorganic fertilizer alone[10].

Organic farming is a practice to achieve sustainability in crop production without endangering soil properties, rather improving it. In this type of farming normally different composts, organic manures and their extracts are used in order to enhance soil fertility and opposing various kind of diseases and pests [11]. These sources had a significant effects on crop quality and production potential [12]. Use combine application of fertilizers and manures is a traditional method to improve soil fertility and enhance crop yield [13]. Compost application increase soil microbial activities and enhance nutrient and carbon concentration in soils [14]. Organic manure acts as sponge in soil and thus improves soil water and nutrient holding capacity by improving soil physical properties, in accompanied with increasing soil fertility, organic manures also improve crop growth rate and water use efficiency [15]. Compost application improves germination of seeds and dry matter yield of crop as compared to no compost application [16].

Keeping in view the importance of composts, poultry manure, urea and beneficial microorganisms the current research was conducted to evaluate the efficacy of these factors for higher wheat productivity.

\section{Materials and methods}

To evaluate the "effect of fresh and composted poultry manure, urea and beneficial microbes on growth of wheat" an experiment was conducted at Agronomy Research Farm, The University of Agriculture Peshawar Pakistan, duringfall 2016-2017. The experiment was laid out in randomize complete block design (RCBD) having three replications. The organic sources were analyzed for $\mathrm{N}$ and $\mathrm{P}$ content. Fully composted and partially composted poultry manure were applied at the rate of 5.21 tha $^{-1}$ and poultry manure sole was applied at the rate of $5.71 \mathrm{t} \mathrm{ha}^{-1}$ to meet the required nitrogen amount $120 \mathrm{~kg} \mathrm{ha}{ }^{-1}$. Layout was established with the plot size of $3 \mathrm{~m} \times 2.4 \mathrm{~m}$ having 8 rows $30 \mathrm{~cm}$ apart from each other. Wheat variety 'Pirsabak 2013' was sown at the rate of $120 \mathrm{~kg}$ seed ha-1 at proper moisture condition on November 25 , 2016. All other cultural practices like irrigation, hoeing were practiced uniformly in each plot.

\section{Preparation of compost}

Pits were dug out, each pit was $1.8 \mathrm{~m}$ long, $1.5 \mathrm{~m}$ wide and $1 \mathrm{~m}$ deep. The pits were 
filled with poultry manure in moist condition and covered with plastic sheet. The pits were closed and poultry manure was buried for 5, 10, 15 and 20 days. The compost materials were turned over after 5 days interval in order to speed up composting process and aeration. Beneficial microbes were applied at the rate of $50 \mathrm{~L} \mathrm{ha}^{-1}$ to four pits and four pits were without beneficial microbes.

The following factors were kept in consideration:

Factor A: Compost duration (days)

5, 10, 15 and 20 days

\section{Factor B: Composting conditions}

Compost only, 50\% Compost and 50\% urea Factor C: Beneficial microorganisms

Control, $50 \mathrm{~L} \mathrm{ha}^{-1}$ (Applied at the time of composting)

The treatments also contain a sole treatment of poultry manure, sole urea, mix treatment $(50 \%$ urea $+50 \%$ poultry manure), machine compost and a control treatment with no $\mathrm{N}$ fertilizer and BM for comparison.

\section{Procedure for recording data}

\section{Emergence $\mathbf{m}^{-2}$}

Emergence data was recorded by counting number of plants emerged in one meter long row at three random places in each plot and were converted using the given formula:

$$
\text { Emergence } \mathrm{m}^{-2}=\frac{\text { No.of seedling counted }}{\text { Row }- \text { row distance }(0.3 \mathrm{~m}) \times \text { Row length }(3 \mathrm{~m}) \times \text { No. of rows (3) }}
$$

\section{Number of leaves tiller-1}

Number of leaves tiller ${ }^{-1}$ were obtained at anthesis stage by counting the number of leaves at post anthesis stage in randomly selected 10 tillers and average was calculated.

\section{Leaf area tiller-1}

Leaf area tiller $^{-1}$ was measured by collecting leaves from randomly selected

$$
\text { Leaf areatiller }^{-1}=\frac{\text { No. of leaves x avg.leaf length }(\mathrm{cm}) \times \text { avg.leaf width }(\mathrm{cm}) \times 0.65}{\text { Number of tiller }}
$$

\section{Leaf area index}

Leaf area index was calculated as the product of leaf area tiller ${ }^{-1}$ and tillers $\mathrm{m}^{-2}$ divided by 10,000 . Leaf area tiller ${ }^{-1}$ was calculated by multiplying the average length and width of five randomly

$$
\text { Leaf area index }=\frac{\text { leaf area tiller-1 } \times \text { no. of tillers } \mathrm{m}^{-2}}{10000 \mathrm{~cm}^{2}}
$$

\section{Days to anthesis}

Data on days to anthesis were recorded by counting the number of days from sowing till $80 \%$ plants reached anthesis.

\section{Plant height $(\mathrm{cm})$}

At physiological maturity, ten tillers were randomly measured from ground level to tip of the plant including spikes and excluding awns. Average was calculated.

\section{Days to maturity}

Days to maturity data were collected by counting the number of days from sowing five tillers in each plot in four central rows at anthesis stage. Their leaf area was calculated by multiplying the product of average leaf length (excluding leaf sheath) and average leaf width with correction factor [17] and total number of leaves which was then divided by the number of tillers to get the leaf area tiller-1. selected tillers with correction factor (0.65). Tiller $\mathrm{m}^{-2}$ were calculated by counting the number of tillers in two central rows in each plot and was converted into $\mathrm{m}^{-}$ 2 .

till $80 \%$ plants reached to physiological maturity indicated by turning yellow the color of spikes [18].

\section{Statistical analysis}

The recorded data were subjected to statistical analysis using Microsoft Excel package according to randomized complete block design and means were compared using least significant difference test (LSD) at 5\% level of probability upon obtaining significant Fvalue. 


\section{Results}

\section{Emergence $\mathbf{m}^{-2}$}

Emergence $\mathrm{m}^{-2}$ of wheat was nonsignificantly affected by different compost duration (D), compost condition (C), beneficial microorganisms (BM), machine vs pit compost, control vs fertilized, poultry manure (PM) vs urea, PM vs mixed, urea vs mixed and interaction between BM and fertilizer $(\mathrm{F})$ treatments (Table 1).

Number of leaves tiller-1

Number of leaves tiller ${ }^{-1}$ of wheat were non significantly affected by different compost duration (D), compost condition (C), beneficial microorganisms (BM), machine vs pit compost, control vs fertilized, PM vs urea, PM vs mixed, urea vs mixed and interaction between $\mathrm{BM}$ and fertilizer $(\mathrm{F})$ treatments (Table 2).

\section{Leaf area $\operatorname{tiller}^{-1}\left(\mathrm{~cm}^{2}\right)$}

Compost duration (D), compost condition (C), beneficial microorganisms (BM), machine vs pit compost and control vs fertilized significantly affected leaf area tiller $^{-1}$ of wheat, while PM vs urea, PM vs mixed, urea vs mixed and the interactions between $\mathrm{D} \times \mathrm{C}$ and $\mathrm{BM} \times \mathrm{F}$ were nonsignificant (Table 3). Mean values of compost duration indicated that minimum leaf area tiller-1 $\left(108 \mathrm{~cm}^{2}\right)$ was recorded at compost duration of 5 days. Leaf area was decreased with increasing compost duration and greater leaf area tiller-1 $\left(125 \mathrm{~cm}^{2}\right)$ was recorded with compost duration of 15 days. Thereafter no significant increase was observed. In case of compost condition, addition of compost only produced lower leaf area $\left(115 \mathrm{~cm}^{2}\right)$ compared to addition of compost along with urea in 50:50 ratio (124 $\mathrm{cm}^{2}$ ).

The BM applied plots produced greater leaf area $\left(124 \mathrm{~cm}^{2}\right)$ compared with no BM application $\left(115 \mathrm{~cm}^{-2}\right)$. The planned mean comparison revealed that greater leaf area tiller $^{-1}$ was recorded in fertilized plots (118 $\mathrm{cm}^{2}$ ) compared to control plots $\left(93 \mathrm{~cm}^{2}\right)$. Pit compost produced greater leaf area (119 $\mathrm{cm}^{2}$ ) compared to machine compost (109 $\mathrm{cm}^{2}$ ).

Table 1. Emergence $\mathrm{m}^{-2}$ of wheat as affected by different PM,compost duration, compost conditions and beneficial microbes

\begin{tabular}{|c|c|c|c|}
\hline \multirow{2}{*}{ Compost duration (days) } & \multicolumn{2}{|c|}{ Beneficial Microbes $(\mathrm{BM})\left(\mathrm{L} \mathrm{ha}^{-1}\right)$} & \multirow{2}{*}{ Mean } \\
\hline & 50 & ( & \\
\hline 5 & 147 & 141 & 144 \\
\hline 10 & 134 & 136 & 135 \\
\hline 15 & 150 & 150 & 150 \\
\hline 20 & 157 & 151 & 154 \\
\hline $\operatorname{LSD}(0.05)$ & & & ns \\
\hline \multicolumn{4}{|c|}{ Compost condition } \\
\hline Compost only & 157 & 149 & 153 \\
\hline $1 / 2$ compost $+1 / 2$ Urea & 136 & 139 & 138 \\
\hline \multicolumn{2}{|l|}{ Significance } & & ns \\
\hline Mean & 147 & 144 & ns \\
\hline \multicolumn{4}{|c|}{ Planned Mean Comparisons } \\
\hline Contrast & Mean 1 & Mean 2 & Significance \\
\hline Control vs fertilized & 146 & 145 & ns \\
\hline Machine vs pit compost & 145 & 145 & ns \\
\hline PM vs mixed & 148 & 137 & ns \\
\hline PM vs Urea & 148 & 150 & ns \\
\hline Urea vs mixed & 150 & 137 & ns \\
\hline \multicolumn{4}{|c|}{ Interactions } \\
\hline $\mathrm{D} \times \mathrm{C}$ & ns & & \\
\hline $\mathrm{BM} \times \mathrm{F}$ & ns & & \\
\hline
\end{tabular}


Table 2. Number of leaves tiller-1 of wheat as affected by different PM, compost duration, compost conditions and beneficial microbes

\begin{tabular}{|c|c|c|c|}
\hline \multirow{2}{*}{ Compost duration (days) } & \multicolumn{2}{|c|}{ Beneficial Microbes (BM) $\left(\mathrm{L} \mathrm{ha}^{-1}\right)$} & \multirow{2}{*}{ Mean } \\
\hline & 50 & $\mathbf{0}$ & \\
\hline 5 & 6 & 6 & 6 \\
\hline 10 & 7 & 7 & 7 \\
\hline 15 & 6 & 7 & 6 \\
\hline 20 & 6 & 7 & 6 \\
\hline $\operatorname{LSD}(0.05)$ & & & ns \\
\hline \multicolumn{4}{|c|}{ Compost condition } \\
\hline Compost only & 6 & 6 & 6 \\
\hline $1 / 2$ compost $+1 / 2$ Urea & 6 & 7 & 7 \\
\hline \multicolumn{2}{|l|}{ Significance } & & ns \\
\hline Mean & 6 & 6 & ns \\
\hline \multicolumn{4}{|c|}{ Planned Mean Comparisons } \\
\hline Contrast & Mean 1 & Mean 2 & Significance \\
\hline Control vs fertilized & 6 & 6 & ns \\
\hline Machine vs pit compost & 6 & 6 & ns \\
\hline PM vs mixed & 7 & 6 & $\mathrm{~ns}$ \\
\hline PM vs Urea & 7 & 6 & $\mathrm{~ns}$ \\
\hline Urea vs mixed & 6 & 6 & ns \\
\hline \multicolumn{4}{|c|}{ Interactions } \\
\hline $\mathrm{D} \times \mathrm{C}$ & $\mathrm{ns}$ & & \\
\hline $\mathrm{BM} \times \mathrm{F}$ & $\mathrm{ns}$ & & \\
\hline
\end{tabular}

Table 3. Leaf area tiller-1 of wheat as affected by different PM,compost duration, compost conditions and beneficial microbes

\begin{tabular}{|c|c|c|c|}
\hline \multirow{2}{*}{ Compost duration (days) } & \multicolumn{2}{|c|}{ Beneficial Microbes (BM) $\left(\mathrm{L} \mathrm{ha}^{-1}\right)$} & \multirow{2}{*}{ Mean } \\
\hline & 50 & $\mathbf{0}$ & \\
\hline 5 & 109 & 106 & $108 \mathrm{c}$ \\
\hline 10 & 122 & 115 & $119 \mathrm{~b}$ \\
\hline 15 & 130 & 120 & $125 \mathrm{a}$ \\
\hline 20 & 136 & 117 & $126 \mathrm{a}$ \\
\hline $\mathrm{LSD}(0.05)$ & & & 6 \\
\hline \multicolumn{4}{|c|}{ Compost condition } \\
\hline Compost only & 121 & 109 & $115 \mathrm{~b}$ \\
\hline $1 / 2$ compost $+1 / 2$ Urea & 128 & 120 & $124 \mathrm{a}$ \\
\hline \multicolumn{2}{|l|}{ Significance } & & $* *$ \\
\hline Mean & $124 \mathrm{a}$ & $115 \mathrm{~b}$ & $* *$ \\
\hline \multicolumn{4}{|c|}{ Planned Mean Comparisons } \\
\hline Contrast & Mean 1 & Mean 2 & Significance \\
\hline Control vs fertilized & 93 & 118 & *** \\
\hline Machine vs pit compost & 109 & 119 & $* *$ \\
\hline PM vs mixed & 116 & 117 & ns \\
\hline PM vs Urea & 116 & 114 & ns \\
\hline Urea vs mixed & 114 & 117 & ns \\
\hline \multicolumn{4}{|c|}{ Interactions } \\
\hline $\mathrm{D} \times \mathrm{C}$ & ns & & \\
\hline $\mathrm{BM} \times \mathrm{F}$ & ns & & \\
\hline
\end{tabular}




\section{Leaf area index (LAI)}

Leaf area index (LAI) of wheat was significantly affected by different compost duration (D), compost condition (C), beneficial microorganisms (BM), control vs fertilized and interaction between $\mathrm{D} \times \mathrm{C}$, while machine vs pit compost, PM vs urea, PM vs mixed, urea vs mixed and the interaction between BM and $\mathrm{F}$ were non-significant (Table 4). Minimum LAI (3.3) was recorded at compost duration of 5 days. LAI was decreased with increasing compost duration and greater LAI (4.0) was recorded with compost duration of 15 days. Thereafter no significant increase was observed. In case of compost condition, LAI was lower (3.4) with addition of compost only compared to addition of compost along with urea in 50:50 ratio (4.1).

The BM applied plots had greater LAI (4.0) compared with no BM application (3.5). The planned mean comparison revealed that higher LAI was recorded in fertilized plots (3.7) compared to control plots (1.9). The interaction between compost duration and condition revealed that LAI increased with increasing compost duration up to 10 days when only compost was applied and thereafter no increase was observed, however increasing compost duration increased LAI when compost was applied along with urea (Figure 1).

\section{Days to anthesis}

Days to anthesis of wheat was significantly affected by different compost duration (D), compost condition (C), beneficial microorganisms (BM), control vs fertilized, PM vs urea and urea vs mixed, while machine vs pit compost, $\mathrm{PM}$ vs mix and the interactions between $\mathrm{D} \times \mathrm{C}$ and $\mathrm{BM} \times \mathrm{F}$ were found nonsignificant (Table 5). Mean values of the compost duration revealed that minimum days to anthesis (128) were recorded at compost duration of 5 days. Anthesis was delayed with increasing compost duration and maximum days to anthesis (130) were recorded with compost duration of 20 days. Regarding compost condition, addition of compost only took minimum days to anthesis (128) compared to addition of compost along with urea in 50:50 ratio (130).

The BM applied plots took more days to anthesis (129) compared with no BM application (128). The planned mean comparison revealed that more days to anthesis were taken by fertilized plots (129) compared to control plots (125). Urea took more days to anthesis (130) compared to PM (127) and mix (128).

Table 4. Leaf area index of wheat as affected by different PM,compost duration, compost conditions and beneficial microbes

\begin{tabular}{|c|c|c|c|}
\hline \multirow{2}{*}{ Compost duration (days) } & \multicolumn{2}{|c|}{ Beneficial Microbes $(\mathrm{BM})\left(\mathrm{L} \mathrm{ha}^{-1}\right)$} & \multirow{2}{*}{ Mean } \\
\hline & $\mathbf{5 0}$ & $\mathbf{0}$ & \\
\hline 5 & 3.4 & 3.1 & $3.3 \mathrm{c}$ \\
\hline 10 & 3.8 & 3.4 & $3.6 \mathrm{~b}$ \\
\hline 15 & 4.2 & 3.7 & $4.0 \mathrm{a}$ \\
\hline 20 & 4.5 & 3.6 & $4.1 \mathrm{a}$ \\
\hline $\operatorname{LSD}(0.05)$ & & & 0.2 \\
\hline \multicolumn{4}{|c|}{ Compost condition } \\
\hline Compost only & 3.6 & 3.1 & $3.4 \mathrm{~b}$ \\
\hline $1 / 2$ compost $+1 / 2$ Urea & 4.4 & 3.8 & $4.1 \mathrm{a}$ \\
\hline \multicolumn{2}{|l|}{ Significance } & & ** \\
\hline Mean & 4.0 & 3.5 & $* *$ \\
\hline \multicolumn{4}{|c|}{ Planned Mean Comparisons } \\
\hline Contrast & Mean 1 & Mean 2 & Significance \\
\hline Control vs fertilized & 1.9 & 3.6 & $* *$ \\
\hline Machine vs pit compost & 3.5 & 3.7 & $*$ \\
\hline PM vs mixed & 3.5 & 3.5 & $\mathrm{~ns}$ \\
\hline PM vs Urea & 3.5 & 3.3 & ns \\
\hline Urea vs mixed & 3.3 & 3.5 & ns \\
\hline \multicolumn{4}{|c|}{ Interactions } \\
\hline $\mathrm{D} \times \mathrm{C}$ & $*$ & & \\
\hline $\mathrm{BM} \times \mathrm{F}$ & ns & & \\
\hline
\end{tabular}




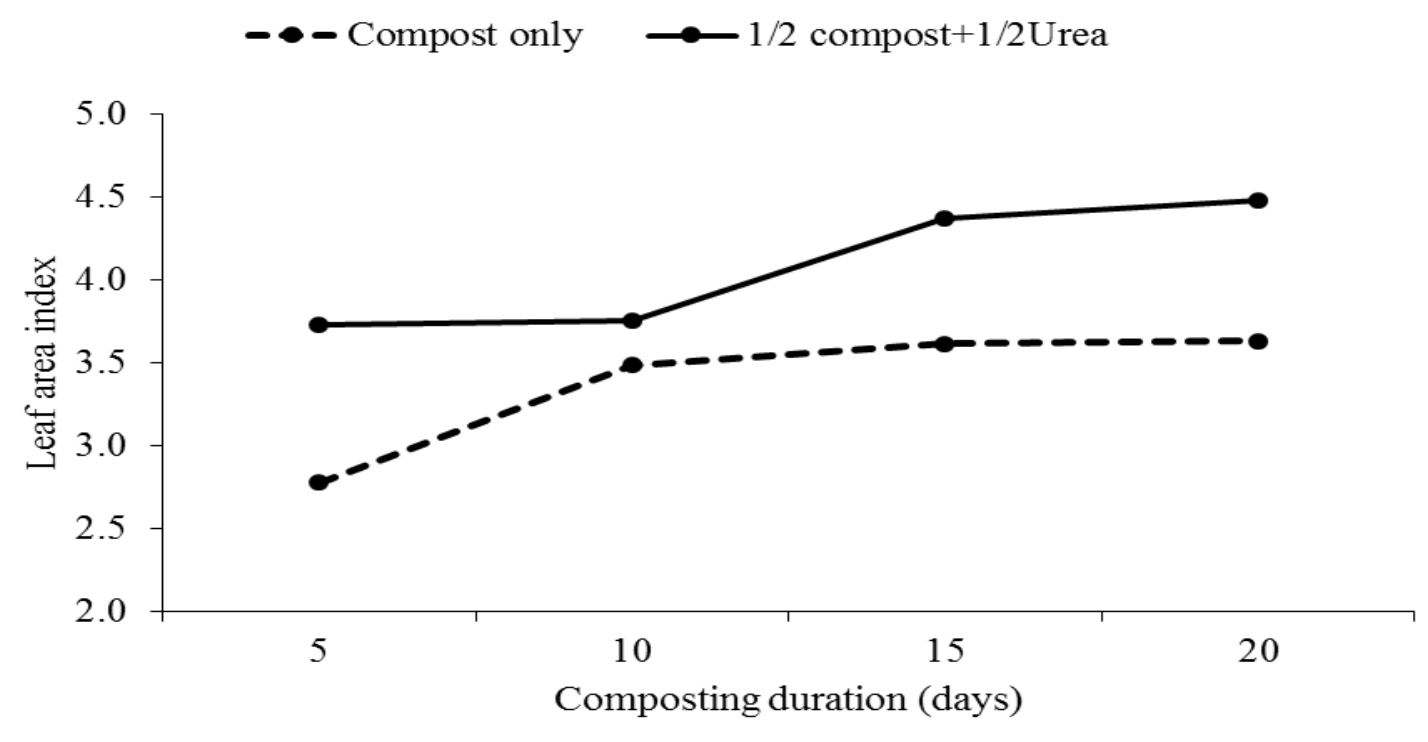

Figure 1. Interaction between compost duration and compost condition for LAI of wheat

Table 5. Days to anthesis of wheat as affected by different PM,compost duration, compost conditions and beneficial microbes

\begin{tabular}{|c|c|c|c|}
\hline \multirow{2}{*}{ Compost duration (days) } & \multicolumn{2}{|c|}{ Beneficial Microbes $(\mathrm{BM})\left(\mathrm{L} \mathrm{ha}^{-1}\right)$} & \multirow{2}{*}{ Mean } \\
\hline & 50 & $\mathbf{0}$ & \\
\hline 5 & 128 & 128 & $128 \mathrm{c}$ \\
\hline 10 & 129 & 128 & $129 \mathrm{~b}$ \\
\hline 15 & 130 & 129 & $129 \mathrm{~b}$ \\
\hline 20 & 130 & 129 & $130 \mathrm{a}$ \\
\hline $\operatorname{LSD}(0.05)$ & & & 1 \\
\hline \multicolumn{4}{|c|}{ Compost condition } \\
\hline Compost only & 128 & 127 & 128 \\
\hline $1 / 2$ compost $+1 / 2$ Urea & 131 & 130 & 130 \\
\hline \multicolumn{2}{|l|}{ Significance } & & $* *$ \\
\hline Mean & 129 & 128 & $* *$ \\
\hline \multicolumn{4}{|c|}{ Planned Mean Comparisons } \\
\hline Contrast & Mean 1 & Mean 2 & Significance \\
\hline Control vs fertilized & 125 & 129 & $* *$ \\
\hline Machine vs pit compost & 128 & 129 & $\mathrm{~ns}$ \\
\hline PM vs mixed & 127 & 128 & ns \\
\hline PM vs Urea & 127 & 130 & $* *$ \\
\hline Urea vs mixed & 130 & 128 & $* *$ \\
\hline \multicolumn{4}{|c|}{ Interactions } \\
\hline $\mathrm{D} \times \mathrm{C}$ & ns & & \\
\hline $\mathrm{BM} \times \mathrm{F}$ & ns & & \\
\hline
\end{tabular}

Means within the same category followed by different letters are significantly different at $\mathrm{P} \leq 0.05$ using LSD test

\section{Plant height (cm)}

Different compost duration (D), compost condition (C), beneficial microorganisms
(BM), control vs fertilized, machine vs pit compost, PM vs urea and urea vs mix, while $\mathrm{PM}$ vs mix and the interactions between $\mathrm{D}$ 
$\mathrm{X} \quad \mathrm{C}$ and $\mathrm{BM} \quad \mathrm{X} \quad \mathrm{F}$ were found nonSignificantly affected plant height of wheat(Table 6). Mean values of the data regarding compost duration revealed that short stature plants $(91.3 \mathrm{~cm})$ were produced with compost duration of 5 days. Plant height of wheat was increased with increasing compost duration and taller plants $(98.6 \mathrm{~cm})$ were produced with compost duration of 20 days. In case of compost conditions, taller plants $(96.4 \mathrm{~cm})$ were produced with application of compost and urea in 50:50 ratio compared to addition of compost only $(93.7 \mathrm{~cm})$.

The BM applied plots produced taller plants $(97.8 \mathrm{~cm})$ compared with no BM application $(92.2 \mathrm{~cm})$. The planned mean comparison revealed that taller plants were produced by fertilized plots $(94.1 \mathrm{~cm})$ compared to control plots $(85.3 \mathrm{~cm})$. Pit compost produced taller plants $(95.0 \mathrm{~cm})$ compared to machine compost $(90.5 \mathrm{~cm})$. Urea application produced taller plants $(96.5 \mathrm{~cm})$ compared to PM $(89.4 \mathrm{~cm})$ and $\operatorname{mix}(92.7 \mathrm{~cm})$.

The BM applied plots produced taller plants $(97.8 \mathrm{~cm})$ compared with no BM application $(92.2 \mathrm{~cm})$. The planned mean comparison revealed that taller plants were produced by fertilized plots $(94.1 \mathrm{~cm})$ compared to control plots $(85.3 \mathrm{~cm})$. Pit compost produced taller plants $(95.0 \mathrm{~cm})$ compared to machine compost $(90.5 \mathrm{~cm})$. Urea application produced taller plants $(96.5 \mathrm{~cm})$ compared to $\mathrm{PM}(89.4 \mathrm{~cm})$ and $\operatorname{mix}(92.7 \mathrm{~cm})$.

Table 6. Plant height $(\mathrm{cm})$ of wheat as affected by different PM,compost duration, compost conditions and beneficial microbes

\begin{tabular}{|c|c|c|c|}
\hline \multirow{2}{*}{ Compost duration (days) } & \multicolumn{2}{|c|}{ Beneficial Microbes (BM) $\left(\mathrm{L} \mathrm{ha}^{-1}\right)$} & \multirow{2}{*}{ Mean } \\
\hline & 50 & $\mathbf{0}$ & \\
\hline 5 & 94.0 & 88.5 & $91.3 \mathrm{c}$ \\
\hline 10 & 96.0 & 92.2 & $94.1 \mathrm{~b}$ \\
\hline 15 & 99.5 & 92.7 & $96.1 \mathrm{~b}$ \\
\hline 20 & 101.8 & 95.5 & $98.6 \mathrm{a}$ \\
\hline $\operatorname{LSD}(0.05)$ & & & 2.4 \\
\hline \multicolumn{4}{|c|}{ Compost condition } \\
\hline Compost only & 95.7 & 91.7 & $93.7 \mathrm{~b}$ \\
\hline $1 / 2$ compost $+1 / 2$ Urea & 99.9 & 92.8 & $96.4 \mathrm{a}$ \\
\hline \multicolumn{2}{|l|}{ Significance } & & $* *$ \\
\hline Mean & $97.8 \mathrm{a}$ & $92.2 \mathrm{~b}$ & $* *$ \\
\hline \multicolumn{4}{|c|}{ Planned Mean Comparisons } \\
\hline Contrast & Mean 1 & Mean 2 & Significance \\
\hline Control vs fertilized & 85.3 & 94.1 & $* *$ \\
\hline Machine vs pit compost & 90.5 & 95.0 & $* *$ \\
\hline PM vs mixed & 89.4 & 92.7 & Ns \\
\hline PM vs Urea & 89.4 & 96.5 & $* *$ \\
\hline Urea vs mixed & 96.5 & 92.7 & $*$ \\
\hline \multicolumn{4}{|c|}{ Interactions } \\
\hline $\mathrm{D} \times \mathrm{C}$ & ns & & \\
\hline $\mathrm{BM} \times \mathrm{F}$ & ns & & \\
\hline
\end{tabular}

Means within the same category followed by different letters are significantly different at $\mathrm{P} \leq 0.05$ using LSD test

\section{Days to maturity}

Days to maturity of wheat was significantly affected by different compost duration (D), compost condition (C), beneficial microorganisms (BM), control vs fertilized and PM vs urea, while machine vs pit compost, PM vs mix, urea vs mix and interactions between $\mathrm{D} \times \mathrm{C}$ and $\mathrm{BM} \times \mathrm{F}$ 
were found non-significant (Table 7). Mean values of the compost duration revealed that minimum days to maturity (182) were recorded at compost duration of 5 days. Maturity was delayed with increasing compost duration and maximum days to maturity (184) were recorded with compost duration of 15 days. There after no significant increase was observed. Regarding compost condition, addition of compost only took minimum days to maturity (182) compared to addition of compost along with urea in 50:50 ratio (185).

The BM applied plots took more days to maturity (184) compared with no BM application (183). The planned mean comparison revealed that more days to maturity were taken by fertilized plots (183) compared to control plots (179). Urea took more days to maturity (184) compared to PM (181).

Table 7. Days to maturity of wheat as affected by different PM,compost duration, compost conditions and beneficial microbes

\begin{tabular}{|c|c|c|c|}
\hline \multirow{2}{*}{ Compost duration (days) } & \multicolumn{2}{|c|}{ Beneficial Microbes (BM) $\left(\mathrm{L} \mathrm{ha}^{-1}\right)$} & \multirow{2}{*}{ Mean } \\
\hline & 50 & $\mathbf{0}$ & \\
\hline 5 & 182 & 182 & $182 \mathrm{c}$ \\
\hline 10 & 184 & 182 & $183 \mathrm{~b}$ \\
\hline 15 & 185 & 184 & $184 \mathrm{a}$ \\
\hline 20 & 184 & 183 & $184 \mathrm{a}$ \\
\hline $\operatorname{LSD}(0.05)$ & & & 1 \\
\hline \multicolumn{4}{|c|}{ Compost condition } \\
\hline Compost only & 182 & 181 & $182 \mathrm{~b}$ \\
\hline $1 / 2$ compost+1/2Urea & 185 & 184 & $185 \mathrm{a}$ \\
\hline \multicolumn{2}{|l|}{ Significance } & & $* *$ \\
\hline Mean & 184 & 183 & $*$ \\
\hline \multicolumn{4}{|c|}{ Planned Mean Comparisons } \\
\hline Contrast & Mean 1 & Mean 2 & Significance \\
\hline Control vs fertilized & 179 & 183 & $* *$ \\
\hline Machine vs pit compost & 183 & 183 & ns \\
\hline PM vs mixed & 181 & 182 & ns \\
\hline PM vs Urea & 181 & 184 & $* *$ \\
\hline Urea vs mixed & 184 & 182 & ns \\
\hline \multicolumn{4}{|c|}{ Interactions } \\
\hline $\mathrm{D} \times \mathrm{C}$ & $\mathrm{ns}$ & & \\
\hline $\mathrm{BM} \times \mathrm{F}$ & ns & & \\
\hline
\end{tabular}

Means within the same category followed by different letters are significantly different at $\mathrm{P} \leq 0.05$ using LSD test

\section{Discussion}

Emergence $\mathrm{m}^{-2}$ of wheat was nonsignificantly affected by different compost duration (D), compost condition (C), beneficial microorganisms (BM), machine vs pit compost, control vs fertilized, poultry manure (PM) vs urea, PM vs mixed, urea vs mixed and interaction between BM and fertilizer $(F)$ treatments. Its might be due to emergence depends on endosperm of seeds, however, nutrients had little or no effect on seed emergences [19]. Our results are in line with [20-23] who stated that emergence was not affected by fresh, compost manures as well as synthetic fertilizers.

Days to anthesis and maturity of wheat was significantly affected by different compost duration (D), compost condition (C), beneficial microorganisms (BM), control vs fertilized, PM vs urea and urea vs mixed. It 
might be due to repaid decomposition of organic fertilizers by beneficial microbes which may be enhanced delayed anthesis and maturity. Our results are in line with the results of [23] who reported that nitrogen is responsible for delayed anthesis and maturity when applied from organic or syntheticsources. Beneficial microbes increase decomposition rates which might have delayed anthesis and maturity of crops [24]. Organic or synthetic fertilized plots significantly delayed phenology as compared to controls plots [25].

Number of leaves tiller ${ }^{-1}$ of wheat was nonsignificantly affected by different compost duration (D), compost condition (C), beneficial microorganisms (BM), machine vs pit compost, control vs fertilized, PM vs urea, PM vs mixed, urea vs mixed and interaction between $\mathrm{BM}$ and fertilizer $(\mathrm{F})$ treatments. It might be due to the fact that leaves tiller $^{-1}$ usually influenced by genotype, nutrient provision and planting density of crop. Our results agree with [26] who reported that fertilizer had no or little effect on number of leaves tiller ${ }^{-1}$.

Leaf area tiller ${ }^{-1}$ and leaf area index of wheat was considerably affected by different compost duration (D), compost condition (C), beneficial microorganisms (BM), machine vs pit compost and control vs fertilized. This might be due to the fact thatBM enhances organic matter decomposition in the soil which might have increased nutrient availability and thus increased leaf area and LAI of the plants. Similar results were earlier presented by [27] who stated that application of beneficial microbes increased leaf area per plant when applied with organic manures. [28] also reported that greater leaf area can be achieved with application of abundant nitrogen regardless of sources, they also stated that crop growth is mainly associated with availability of nitrogen in soils. Similarly [29] reported a significant increase in leaf area with application of fertilizers as compared to control treatment. Plant height of wheat was significantly affected by different compost duration (D), compost condition (C), beneficial microorganisms (BM), control vs fertilized, machine vs pit compost, PM vs urea and urea vs mix.Plant height is primarily influenced by genetic variations in the genotypes but it is also influenced by nutrients supply and nutrient management practices as well as phenotypic variations [30]. The increase in plant height with addition of BM might be due to accelerated decomposition of organic matter in soil which enhanced nutrients availability to plants. Similar findings were earlier stated by $[31,27]$ who observed taller plants with the addition of BM. The probable reason for increase in plant height with addition of complete compost in comparison with partial compost might be the variation in $\mathrm{C}: \mathrm{N}$ ratio of the feed stock which is associated with nutrients availability [32]. Likewise [33] reported taller plants with addition of urea and compost in combine form. Pit compost was proved superior to machine compost which might be due to the complete decomposition of organic material in pit as compared to machine compost [34].

\section{Conclusion}

It was concluded that compost duration of 15 days along with urea in 50:50 ratio and addition of beneficial microorganisms at the rate of $50 \mathrm{~L} \mathrm{ha}^{-1}$ increase crop growth while the pit compost was found superior as compared to machine compost. So application of 15 days older compost along with urea in 50:50 ratio with beneficial microorganisms is recommended for higher wheat productivity.

\section{Authors' contributions}

Conceived and designed the experiments: A Liaqat \& F Nawaz, Performed the experiments: A Liaqat, Analyzed the data: A Liaqat, S Ullah \& Z Hussain, Contributed materials/ analysis/ tools: A Liaqat, AR Khan, Wrote the paper: N Khan.

\section{References}

1. MNFSR (2015). Agriculture statistics of Pakistan. Ministry of National Food Security and Research (Economic wing) Islamabad. 
2. PABA (2016). Pakistan American Business Association. Pakistan's Wheat Production in 2015-16.

3. Ahmad W, Jan MT, Ilyas M, Shah T, Ullah M, Azeem K, Ahmad A \& Khan $S$ (2017). Phenology and yield components of maize as influenced by different forms of dairy manure with supplemental nitrogen management. Inter J Agric Env Res 3(1): 137-146.

4. Farhad W, Saleem MF, Cheema MA \& Hammad HM (2009). Effect of poultry manure levels on the productivity of spring maize (Zea mays L.). J Anim Plant Sci 19(3): 122-125.

5. Cheema M.A, Farhad W, Saleem MF, Khan HZ, Munir A, Wahid MA, Rasul F \& Hammad HM (2010). Nitrogen management strategies for sustainable maize production. Crop Environ 1: 4952.

6. Khan M.A, Abid M, Hussain N \& Masood MU (2005). Effect of phosphorous levels on growth and yield of maize cultivars under saline conditions. Inter J Agri Biol 3: 511514.

7. Sharif M, Ahmed M, Shahrir MS \& Khattak RA (2004). Effect of organic and inorganic fertilizers on the yield and yield components of maize. Pak $J$ Agri Engg Vet Sci 20 (1): 11-15.

8. Bair CA (2000). Methods of Soil Analysis. Part I and II. Amer. Soc. Agron. Inc. Pub. Madison, Wisconsin, USA.

9. Nambiar KKM (2000). Long term fertility effects on wheat productivity. In: Proc. wheat for non-traditional warm areas, (Saunders, O.A. ed), CIMMYT I, pp 516-521.

10. Akhtar M, Asif N, Javed A, Bokhari SA \& Wajid I (2011). Improvement in nutrient uptake and yield of wheat by combine use of urea and compost. Soil Environ Sci 30(1): 45-49.

11. Khadem SA, Galavi M, Ramrodi M, Mousavi SR, Rousta MJ \& RezvaniMoghadam P (2010). Effect of animal manure and superabsorbent polymer on corn leaf relative water content, cell membrane stability and leaf chlorophyll content under dry condition. Aus J Crop Sci 4(8): 642647.

12. Toor PS, Antil RS, Bgarat S \& Kuhad MS (2009). Effect of different levels of nitrogen and glue waste on wheat. Ann Bio 16(2): 147-151.

13. Sandeen A \& Gamroth M (2003). Composting, an alternative for livestock manure management and disposal of dead animals. EM 8825 Murch 2003. Oregon state university.

14. Caravaca F, Figueroa D, Alguacil MM \& Rolan A (2003). Application of composted urban residue enhanced the performance of afforested shrub species in a degraded semiarid Land. Biores Technol 90: 65-70.

15. Karlen DM \& Camp CR (1985). Row spacing plant population, and water management effect on corn in the in the Atlanta coastal plain. Agron J 77: 393398.

16. Mc-Callum KR, Keeling AA, Beckwith CP \& Kettlewell PS (1998). Effects of green waste compost on spring wheat emergence and early growth. Acta Hort 467: 313-31.

17. Saxena MC \& Singh Y (2010). A note on leaf area estimation of intact maize leaves. Indian J Agron 10: 437-439.

18. Mohsin AU, Ahmad J, Ahmad AHU, Ikram RM \& Mubeen K (2012). Effect of nitrogen application through different combinations of urea and farm yard manure on the performance of spring maize (Zea mays L.). $J$ Animal Plant Sci 22(1): 195-198.

19. Amanullah MM, Somasundaram E, Vaiyapuri K \& Sathamoorthi K (2007). Poultry manure to crops-A review. Agric Rev 28(3): 216-222.

20. Loecke TD, Liebman M, Cambardella CA \& Richard TL (2004). Corn responses to composting and time of application of solid swine manure. Agron J 96: 214-223. 
21. Theodora M, Anastasios SL \& Athanasios AG (2003). Effect of injected liquid cattle manure on growth and yield of winter wheat and soil characteristics. Agron J 95: 592-596.

22. Baloch PA, Abro BA, Chandio AS, Depar N \& Ansari MA (2015). Growth and yield response of maize to integrated use of Gliricidiasepium, farm manure and NPK fertilizers. Pak. J. Agri. Agril. Engg. Vet Sci 3(1): 1423.

23. Deldon AV (2001). Yield and growth components of potato and wheat under organic N management. Agron J 93: 1370-1385.

24. Lee KH (1991). Studies on effective microorganisms. Paper presented at the 2ndstreeing committee meeting on APNAN, Kuala Lumpur, Malaysia.

25. Matsi TA, Lithourgidis S \& Gagianas AA (2003). Effect of injected liquid cattle manure on growth and yield of winter wheat and soil characteristics. Agron J 95: 592-596.

26. Muhammad H, Zaman A, Khalil SK \& Shah Z (2014). Effect of beneficial microbes $(\mathrm{BM})$ on the efficiency of organic and inorganic $\mathrm{N}$ fertilizers on wheat crop. Sarhad J Agric 30(1): 714.

27. Azeem K \& Ullah I (2016). Physiological indices of spring maize as affected by integration of beneficial microbes with organic and inorganic nitrogen and their levels. Comm. Soil Sci Plant Anal 47(21): 2421-2432.

28. Fallah A, Ghalavand VM \& Khajepour R (2006). Effects of blending methods of livestock compost with soil and mixing it with chemical compost on yield and parts of yield of seed corn in Khorramabad, Lorestan. Agri Nat Res Sci Mag 40: 233-242.

29. Gul RK, Inamullah, Ullah $\mathrm{H}$, Ali $\mathrm{N} \&$ Anjum MM (2016). Effect of nitrogen level and source management on phenology and growth of maize genotypes. Int. J. Curr. Trend. Pharmacobiol. Med Sci 1(3): 88-95.

30. Amanullah MM, Sekar S \& Muthukrishnan P (2010). Prospects and potential of poultry manure. A review. Asian J Plant Sci 9(4): 172182.

31. Dehghani I, Kordlaghari KP \& Mohamadinia G (2013). Effect of effective microorganisms activate (EMa) on growth, yield and yield components of corn in Firozabad region. Ann Biolog Res 4 (4):126-129.

32. Bilal BAB, Young TM \& Ranieri E (2016). Effects of compost age on the release of nutrients. Inter Soil Water Conserv Res 4: 230-236.

33. Sarwar G, Hussien N, Schmiesky H, Muhammed S, Ibrahim M \& Safdar E (2008). Improvement of soil physical and chemical properties with compost application in rice-wheat cropping system. Pak J Bot 40: 275-282.

34. Khan S, Jan MT, Ahmad B, Shah T \& Ahmad W (2016). Yield and yield components of maize as affected by integrated management of sheep manure and urea fertilizer. Middle East $J$ Agric Res 5(4): 522-533. 